\section{Vietnam Journal of Agricultural Sciences}

Received: June 9, 2019

Correspondence to

lbaoguo@usst.edu.cn

ORCID

Li Baoguo

http://orcid.org/0000-0001-74303889

\title{
Aquaculture Development and Nutrition Management of Large Yellow Croaker (Pseudosciaena crocea) in China: An Overview
}

\author{
Truong Huynh Thanh Hoa ${ }^{1}$, Li Baoguo' \& Guo Quanyou² \\ ${ }^{1}$ School of Medical Instrument and Food Engineering, University of Shanghai for \\ Science and Technology, Shanghai, China \\ ${ }^{2}$ East China Sea Fisheries Research Institute, Chinese Academy of Fishery Sciences, \\ Shanghai, China
}

\begin{abstract}
Aquaculture production in China has made large contributions to the global total volume of fish for human consumption. The developed mariculture fish species large yellow croaker (Pseudosciaena crocea) is the highest economic marine fish of China. As a schooling fish, large yellow croaker (LYC) usually migrates from northeast China to the southeast seacoast to over-winter. Indeed, there are several culture systems that can be applied for large yellow croaker, which should simulate the natural habitat for this fish species. The nutrition management of LYC has attracted researchers to study their nutrient requirements, growth, and other physiological characteristics. Here, we review the general biology (geographic distribution and habitat), hatchery development, aquaculture systems, and nutrition management of LYC. The paper aims to underpin the most significant investigations and highlight the future prospects for the LYC aquaculture industry in China.
\end{abstract}

\section{Keywords}

Geographic distribution, habitat, hatchery, aquaculture system, dietary nutrients

\section{Introduction}

Aquaculture continues to grow faster than other major food production sectors (FAO, 2018). Global fish production peaked at about 171 million tons in 2016, with aquaculture representing 47 percent of the total (FAO). In China, by far the major producer of farmed fish in 2016, contributed 62 percent of the total volume of global aquaculture production in 2016 (FAO, 2018).

As an economically important marine fish, large yellow croaker (Pseudosciaena crocea) (Figure 1) has been cultured for more than three decades in China due to its delicious taste, and nutritional and 


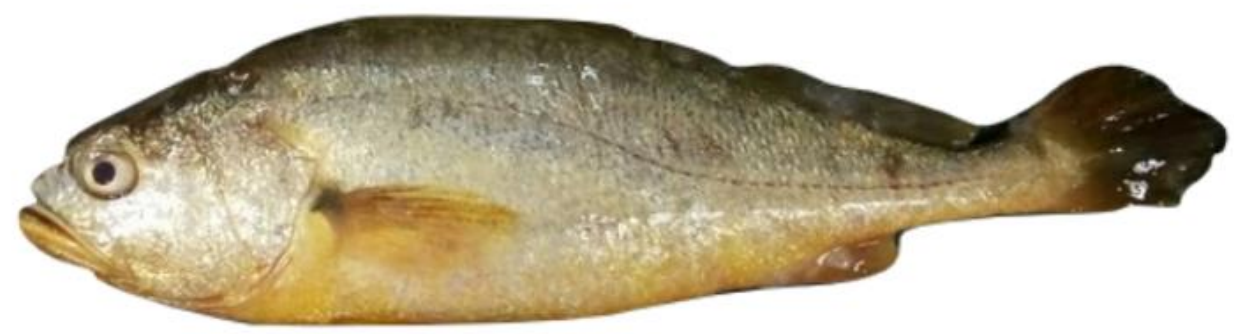

\section{$5 \mathrm{~cm}$}

Figure 1. Large yellow croaker (Pseudosciaena crocea). The photo was taken on January 31, 2018 in a laboratory of the University of Shanghai for Science and Technology, Shanghai-China

economic values (Duan et al., 2001; Wang et al., 2019). They can be grouped into three geographical populations, i.e. Daiquyang, Minyuedong, and Naozhou stocks (Huang \& Walters, 1983; Wang et al., 2013). The majority of large yellow croaker (LYC) are cultured along China's east seacoast in such provinces as Guangdong, Fujian, and Zhejiang (Liu et al., 2008; Chen et al., 2020). According to the China Fishery Bureau, the aquaculture production of LYC reached 177,600 tons in 2017, making LYC the largest contributor to marine aquaculture fish in China (Fishery Bureau, 2018). Since there are huge demands from nation-wide and foreign markets for LYC, the demand for LYC nutrition supplies has also increased. LYC diets and nutritional requirements have been studied since the beginning of the $21^{\text {st }}$ century (Duan et al., 2001). They have included the ideal levels of lipids (Ai et al., 2008), protein (Ai et al., 2006; Duan et al., 2001), amino acids (Mai, et al., 2006; Xie et al., 2012; Zhang, Ai, et al., 2008), fatty acids (Zuo et al., 2012a; 2012b), color pigments (Li et al., 2014; Yi et al., 2014), and other nutrients. The fish growth performance, survival rate, specific growth rate, and proximate compositions have been used as the parameters to evaluate the effectiveness of the experimental diets (Duan et al., 2001; Zhang et al., 2008; Li et al., 2010). Recently, research has focused on physiological studies, such as the antioxidant capacity (Yi et al., 2018), intestinal digestive enzymes (Zhang et al., 2016), and immune responses (Li et al., 2014) of large yellow croaker.

In this paper, we summarize the general biology (geographic distribution, habitat and migration), fisheries and aquaculture developments (hatchery history and culture systems), and nutritional management of large yellow croaker, which is one of the principal marine aquaculture fish species in China.

\section{General biology}

\section{Geographic distribution}

Pseudosciaena crocea has an endemic distribution in the coastal waters of continental East Asia, including East China, northern South China, Southern Yellow Seas, Taiwan, and South Korea (Huang \& Walters, 1983; Chen et al., 2018). Based on the morphological characteristics, geographical habitats, and the structure of the populations, LYC in the China Sea (Figure 2) can be grouped into three geographical stocks, as Daiquyang, Minyuedong, and Naozhou (Huang \& Walters, 1983; Liu et al., 2008; Wang et al., 2013). These stocks are distributed from the southern Yellow Sea to the central East China Sea, the southern East China Sea to the eastern Pearl River, and the western Pearl River to the Leizhou Peninsula, respectively (Liu et al., 2008; Wang et al., 2013). The Daiquyang stock typically has a slow growth rate and late sexual maturation, but also cold tolerance and a long life; the Min-Yuedong stock has an intermediate growth rate with intermediate longevity and sexual maturation; and the Naozhou stock has a fast growth rate, early sexual maturation, and relatively short life (Liu et al., 2008). 


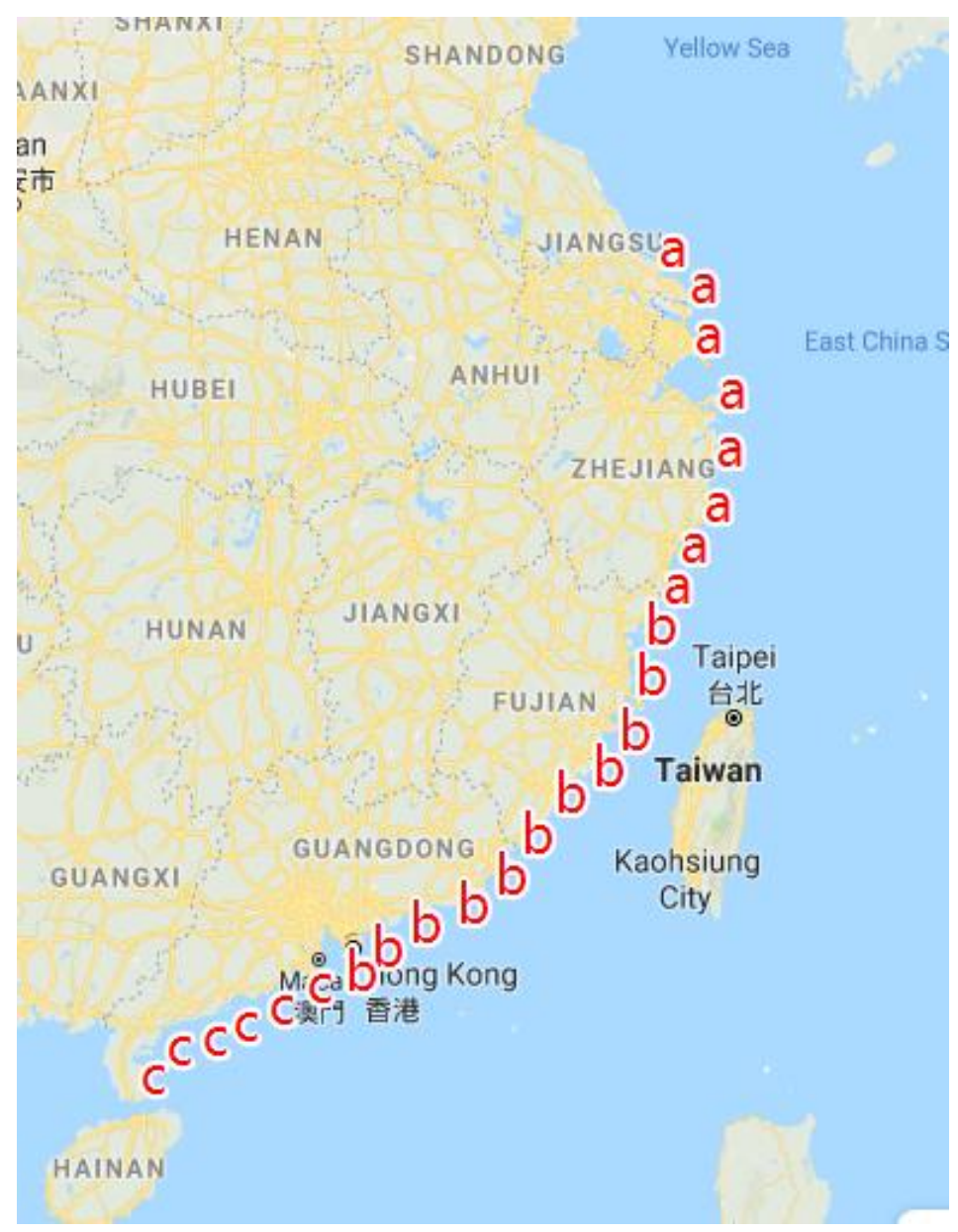

Figure 2. Three putative geographical stocks along the coastal waters of China, the Daiquyang (a), Min-Yuedong (b) and Naozhou (c) stocks. Image is from Google Maps (maps.google.com) and Liu et al. (2008).

\section{Habitat and migration}

The temperature range of $\mathrm{LYC}$ is about 8 $32^{\circ} \mathrm{C}$, while the most suitable temperature is 18 $25^{\circ} \mathrm{C}$. If the temperature is above $30^{\circ} \mathrm{C}$ or below $14^{\circ} \mathrm{C}$, fish will usually reduce their food intake (Zhang, 2003). Large yellow croaker is a broadeating fish, and they can bait hundreds of species of other small fish in the natural environment, e.g. copepods, bran shrimp, krill, and other zooplankton (Zhang, 2003).

LYC is a temperate seawater schooling fish species (Lü et al., 2008). In the central East China Sea area, the large schools of LYC mature in late March and migrate inshore to spawn in shallow coastal waters $(<30 \mathrm{~m})$ during April to June (Huang \& Walters, 1983; Lin, 1987). In the southern East China Sea area, fish mainly spawn from November to January (Lin, 1987). There are about 13 spawning grounds along the China Sea from north to south, namely the South Korea- inshore, Lusiyang, Daiquyang, Damuyang, Maotouyang, Dongtouyang, Guanjingyang, Xiamen-offshore, Nanao-inshore, Shanweioffshore, Hongkong, Naozhou, and Xuwen sites (Huang \& Walters, 1983; Liu et al., 2008). The three most important spawning grounds are Daiquyang and Lusiyang in the northern Zhejiang coastal waters, and Mao-touyang in the middle of Zhejiang coastal waters (Lü et al., 2008). Spawning season coincides with the fishing season. The fishing season begins annually in early April and ends in late June (Huang \& Walters, 1983). As temperatures decrease, LYC moves further east from October to December and over-winter offshore in deeper waters $(50-80 \mathrm{~m})$ from January to March (Lü et al., 2008). The overwintering grounds consist of the southern Yellow Sea, the offshore northern Zhejiang province, and between the southern Zhejiang to southern Fujian Provinces (Liu et al., 2008). 


\section{Fisheries and aquaculture}

\section{Fishery activities}

The number of LYC fisheries declined in the 1970s due to overfishing, and the fish was extremely overexploited by the mid-1980s to 1990s; for example, the harvest dropped from 155,000 tons in 1970 to only 1,700 tons in 1990 (Lü et al., 2008). From April to July of 1981, bottom trawling was stifled along the coast of China to protect LYC during the spawning period (Lü et al., 2008). In 1998, the Chinese government initiated a policy to release and restock LYC in Zhejiang province (Lü et al., 2008). Although no statistics were recorded from 1998 to 2002, there has been an increase in the number of LYC harvested since 2003 (Lü et al., 2008). In 2006, there were 55.2 tons of LYC harvested near the releasing area of the Daiquyang Sea (Lü et al., 2008). To date, the contribution of wild catches is still limited despite the enforced management measures (Liu et al., 2008; Wang et al., 2013; Wang, et al., 2014).

\section{Hatchery development}

Due to the decline of wild stocks, the Chinese government began investing in hatcheries to restore the LYC resources. In 1985, wild stocks of 30 mature female LYC were captured in the Guanjingyang spawning ground, and a total of $1,115,000$ fertilized eggs were obtained (Su et al., 2004). In May of 1987, domesticated broodstocks of 20 pairs were selected for artificial spawning and 100 fry were successfully nursed, which was a milestone for artificial propagation (Chen et al., 2018). In 1990, the second generation consisting of a million fry were artificially hatched successfully without relying on wild-caught broodstock (Su et al., 2004). During the 1990s, with strong support from the Ministry of Agriculture and the Fujian Province government, several projects were approved, including the "Development and research on cultivation techniques of large yellow croaker", "Development and research of artificial breeding technology of large yellow croaker", and "Technical research on the large yellow croaker breeding industry", among others (Chen et al., 2018). These efforts contributed to the development of the LYC aquaculture industry, which made it the largest culture industry of any marine fish in China (Chen et al., 2018). The number of hatcheries in Fujian Province increased nearly 22 times in only 4 years, from 20 hatcheries in 1996 to 432 hatcheries in 2000 (Zhang et al., 2002). In 1999, a hatchery attempt for the Daiquyang stock was launched in Zhejiang Province and 300,000 fry were successfully cultivated in 2000 at the Zhoushan Fisheries Research Institute (Ni \& Lu, 2003).

At the beginning of $21^{\text {st }}$ century, more projects were established to contribute to the LYC aquaculture, e.g. original stock management, disease control, environmental monitoring, technical training, and information network development (Chen et al., 2018). In November of 2011, the "Industrialization of the Daiquyang stock of large yellow croaker aquaculture" was launched in Zhejiang province (Chen et al., 2018). In 2014, the research team of Ming-Yun Li documented the development of a new variety of LYC named Donghai No. 1, the fifth generation of wild stock from Daiquyang in 2000 (Miao et al., 2014). According to the report, in 2012, Donghai No. 1 contributed a higher yield of hatchery-produced fry than that of the local commercial fry in Xiangshan and Fenghua cites, Zhejiang Province (Miao et al., 2014). In October 2015, the State Key Laboratory of Large Yellow Croaker Breeding was launched by Ningde Fufa Fisheries Co., Ltd., which was the first State Key Laboratory of aquaculture enterprises in China (Chen et al., 2018).

To date, the annual national production of China has the potential to increase each year (Yin et al., 2017). The aquaculture production of China has nearly doubled from 85,800 tons in 2010 to 165,496 tons in 2016 (Fishery Bureau, 2011; 2017).

\section{Culture systems}

Aquaculture systems are believed to have an impact on the flesh quality, such as the proximate composition, color, texture, and fatty acid and amino acid profiles of cultured LYC (Zhong et al., 2014; Zhou et al., 2014). To date, the marine aquaculture systems of LYC have developed rapidly (Chen et al., 2020). There are several kinds of culture systems in LYC aquaculture, e.g. 


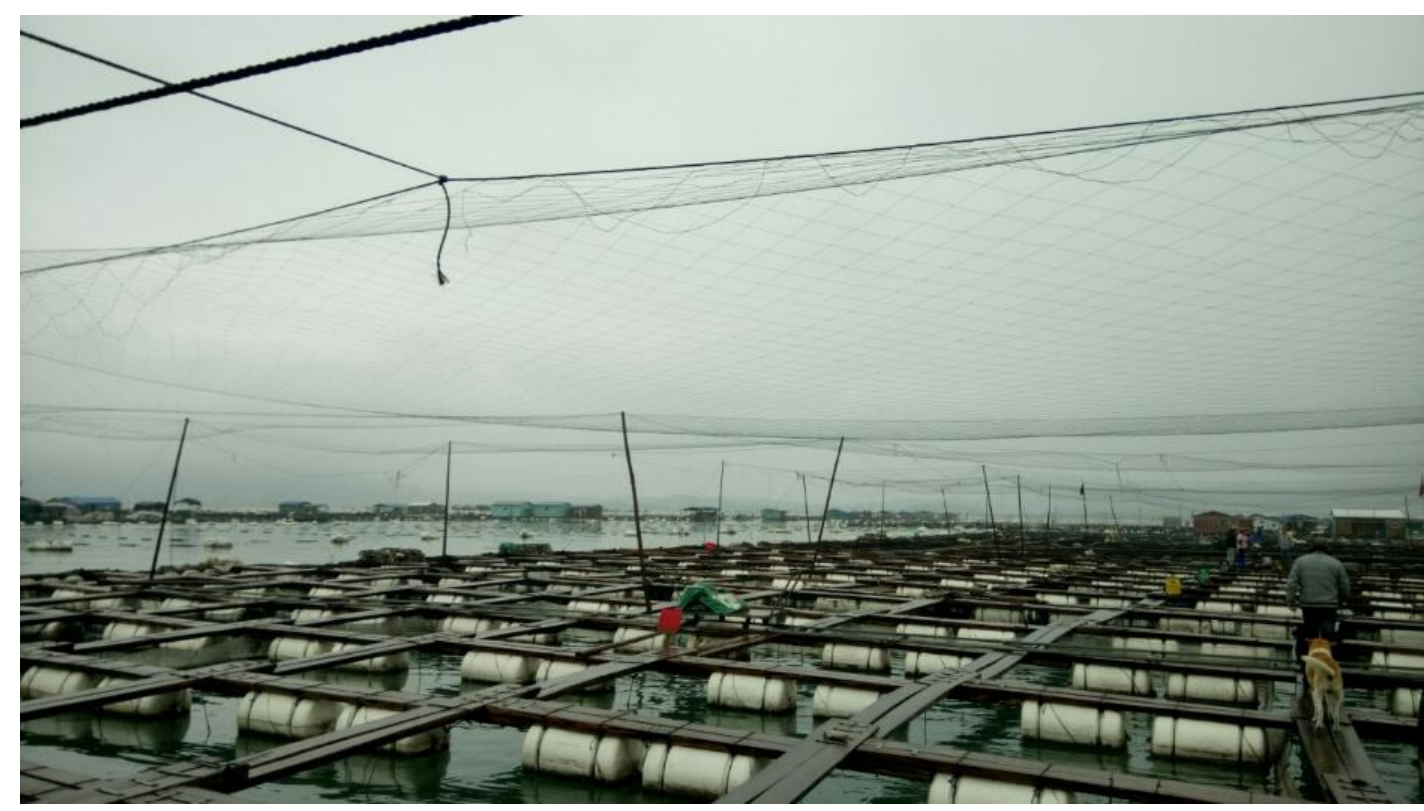

Figure 3. Floating sea cage culture of large yellow croaker

(The photo was taken on January 28, 2018 in Xiapu City-Fujian Province-China)

floating sea cage, earthen pond, enclosure/seine net, storm-resistance deep-sea cage, indoor recirculation system, and the north-south connected farming model. Selecting the best system depends on the local geographic conditions, the economic resources of the anglers, and the scale of the project (Liu, 2013).

The most prevalent system is the floating sea cage, which has developed since the 1980s (Miao et al., 2007) and accounts for $95 \%$ of the yield of LYC species (Hong et al., 2018). Traditional cage culture is generally selected in clear-water harbors where water currents are relatively slow (Figure 3). In the 1990s, floating sea cages, sized $3 \times 3 \times 3 \mathrm{~m}$, usually had a high density of fish, and poor-water exchange capacity and quality, which could easily have changed the migration and habitats of LYC (Miao et al., 2007; Ni \& Wang, 2009). Hence, in 2006, the government launched the "Large yellow croaker standardized cage culture technology" project, which was carried out by fishery science and technology researchers; it began the practice of using new, larger-ranged cages to replace the former small, shallow cages (Hong et al., 2018). To date, each cage is about $4 \times 4 \mathrm{~m}$ standards with the depth ranging from $8-10 \mathrm{~m}$, and an area of $2000 \mathrm{~m}^{2}$ of connected cages forms a cage unit, commonly known as a fish platoon (Hong et al., 2018).
Earthen pond farming is a kind of simulated ecological pattern (Jiang, 2014; Chen et al., 2018). The size of the pond depends on the target population of fish produced but is usually about 3 hectares as the pond needs to have an inflow and draining capacity every day of the year (Jiang, 2014). The south of China, especially Fujian Province, is famous for its abundant marine resources and excellent seawater quality; therefore, it is of practical significance to investigate earthen pond farming and improve the quality of LYC, which can supply market demands and promote the increase of anglers' income (Jiang, 2014).

Enclosure/seine net farming is another kind of simulated ecological pattern that is an ideal system for fish farming. The enclosure net sizes are either $0.2-0.27 \mathrm{hm}^{2}, 1.00-1.33 \mathrm{hm}^{2}$, or bigger than $10 \mathrm{hm}^{2}$, and should be placed in areas with a water depth of more than 5m (Chen et al., 2018; Hong et al., 2018). The seine net has larger space for fish activity, more water exchange, less residual bait, less disease, and high survival rate, and at the same time, there is a certain amount of natural biological bait supplement (Miao \& Li, 2006). It has been approved to contribute to the flesh quality of LYC more than that of the traditional floating sea cages and earthen ponds (Miao et al., 2007; Han et al., 2011; Yan et al., 2015). 
Storm-resistance deep-sea cage/deep-water sea cage farming is a potential solution for LYC aquaculture. The cultured sea area must have the conditions for avoiding strong winds, a suitable temperature for species over-wintering, a water depth more than $10 \mathrm{~m}$, and a water flow below 0.7 $\mathrm{m} \mathrm{s}^{-1}$ (Zhang, 2003). A semi-open bay facing south is generally optimal, as it is relatively less affected by typhoons (Zhang, 2003). In order to avoid typhoons, fish are stocked in October and harvested in June of the following year (Hong et $a l ., 2018)$. The quality of LYC cultured in deepwater sea cages is more preferable with better nutritive quality and flavor than that of traditional sea cages ( Zhong et al., 2014; Guo et al., 2016; Xiao et al., 2017).

Studies utilizing indoor recirculation systems have been recently conducted to test the low salinities of the cultured water (Huang, 2015; Wang et al., 2016). The natural salinity of seawater $(28 \%)$ was reduced to $8,4,2$ or $0.5 \%$; the fish (initial weight of $0.1 \mathrm{~g}$ ) survival rate remained $59 \%$ after 4 months (Huang, 2015). In another study, the salinities of $5 \%$ and $10 \%$ did not have negative effects on the physiological functions of juvenile LYC (initial weight of $0.12 \mathrm{~g}$ ) after 10 weeks (Wang et al., 2016). If the model is successful in the future, it will be applied to indoor recirculation systems with freshwater (Huang, 2015) or saline ponds (salinities from 5\% to 10\%) (Wang et al., 2016).

North-south connected farming is a new model for sustainable development in recent years (Li et al., 2017). Fish would be moved to a suitable temperature area to escape the cold weather in the north and the hot weather in the south. In 2017, Ming-Yun $\mathrm{Li}$ and his team investigated the north-south connected farming model (Li et al., 2017). The fish hatched in Fujian Province would be shifted to Shandong Province to culture in the summer and autumn. As the winter arrived, the fish would be transferred to Fujian for cultivation. The transaction would be continued until the fish reached the market size and could be sold out. The model is believed to contribute to a higher fish growth rate, disease resistance, and better fish quality and flavor (Li et al., 2017).

\section{Nutrition management}

It is crucial to study nutritional management since juvenile nutrition investments are about $70-80 \%$ of the LYC aquaculture total investment (Liao et al., 2011). The nutrition sources of LYC in commercial hatcheries are based on two main sources: the fresh/frozen trash fish diet and commercial compound diet (Liu, 2014; Liu \& Li, 2001).

Fresh/frozen trash fish have basically occupied $80 \%$ of the LYC diets in the markets of Ningde, Fujian Province (Liu, 2014). However, trash fish have some disadvantages to the aquaculture of LYC. Trash fish have limited resources, an unstable supply chain (Liu \& $\mathrm{Li}$, 2001; Liu, 2014), spoil easily, and have nutritional inconsistencies (Liu, 2014). Trash fish residue also pollutes the environment (Wang, 2014). The bacterial communities of fresh/ frozen trash fish for LYC have been studied, and there are several bacteria that could lead to diseases (Wang et al., 2014). Therefore, with the goal of sustainable development, hatcheries should shift to the compound diet.

Compound diets have been increasingly been used since the beginning of the $21^{\text {st }}$ century (Liu \& Li, 2001; Liu, 2014). Since then, studies about LYC nutrition have been multiple and abundant. Studies about the nutritional requirements of LYC larvae and juveniles are summarized as follows.

\section{Larvae diets}

Nutritional information for LYC larvae has been studied from the late 2000s (Ai et al., 2008). Since dietary lipid levels significantly affect the growth and survival rate of LYC larvae, the optimal dietary lipid level was found to be in the range of 172 to $177 \mathrm{~g} \mathrm{~kg}^{-1}$ of diet (Ai et al., 2008). Consequently, Yu et al. (2012) reported that the level of $57.1 \%$ protein with $13.6 \%$ dietary carbohydrates was suitable for LYC larvae with an energetic $16.65 \mathrm{MJ} \mathrm{kg}^{-1}$ diet. Moreover, larvae usually have higher protein requirements in order to break the proteins down into amino acids for rapid growth in early life (Rønnestad et al., 2003). The optimum dietary amino acids pattern contributes to the balance of amino acids required, decreases amino acid oxidation, and 
increases the efficiency of food conversion (Conceição et al., 2003). The effects of dietary amino acids on the growth and protein metabolism of LYC larvae were studied by Li et al. (2013). The amino acid patterns with crystalline-amino acids replacing approximately $40 \%$ of fishmeal protein-bound nitrogen were tested with large yellow croaker egg protein, large yellow croaker larvae whole-body protein, large yellow croaker muscle protein, and white fishmeal protein, respectively. The results showed that the specific growth rate and wholebody protein content obtained were highest in white fishmeal protein $(11.3 \%)$ compared to egg protein, whole-body protein, and muscle protein diets $\left(9.9,10.3\right.$, and $10.6 \%$ day $^{-1}$, respectively). The specific activities of the digestive enzymes and the ratio of "pancreatic enzymes in intestinal segments/pancreatic enzymes in pancreatic segments" were also significantly higher in larvae fed with white fishmeal protein. In addition, the requirement of dietary lysine, an essential amino acid that can promote larvae growth rate, was singly studied by Xie et al. (2012). The optimum lysine level for LYC larvae was estimated to be $33.7 \mathrm{~g} \mathrm{~kg}^{-1}\left(65.5 \mathrm{~g} \mathrm{~kg}^{-1}\right.$ dietary protein) or $33.4 \mathrm{~g} \mathrm{~kg}^{-1}$ (64.9 $\mathrm{g} \mathrm{kg}^{-1}$ dietary protein) based on the maximum growth and survival rate, respectively. Furthermore, the dietary phosphorus requirement level was found to be $57.2 \mathrm{~g} \mathrm{~kg}^{-1}$ dry diet, which can boost the survival rate, growth performance, and stress tolerance for LYC larvae (Zhao et al., 2013).

\section{Juvenile diets}

The evolution of the compound diet began with research on the dietary protein: lipid ratio of LYC (Duan et al., 2001). The authors tested four dietary protein levels $(34,37,42$, and $47 \%)$ and three dietary lipid levels $(7.5,10.5$, and $14.0 \%)$ for juvenile LYC ( $0.57 \mathrm{~g}$ initial weight) for 60 days. White fishmeal, $\alpha$-starch, and wheat flour were used as the main dietary ingredients. Their data suggested that the dietary protein: lipid ratio of 47:10.5 obtained the maximum weight gain, survival rate, feed conversion, and protein efficiency ratio.

Increasing demand, limited availability, and the high price of fishmeal (FM) have resulted in the quest for alternative protein from animal and vegetable resources (Ai et al., 2006; Li et al., 2010). Table 1 shows studies that included different protein sources for juvenile and marketsized LYC. Ai et al. (2006) assessed six isonitrogenous (43\% crude protein) and isoenergetic $\left(20 \mathrm{~kJ} \mathrm{~g}^{-1}\right)$ diets replacing $0,15,30,45,60$, and $75 \%$ FM protein with meat and bone meal protein for LYC (1.88g initial weight) to apparent satiation for 8 weeks (Table 1). The results indicated that $45 \%$ of FM protein could be replaced by meat and bone meal protein without

Table 1. Replacement of fishmeal protein with animal and vegetable resources

\begin{tabular}{|c|c|c|c|c|c|c|c|}
\hline $\begin{array}{l}\text { Replacement } \\
\text { sources }\end{array}$ & $\begin{array}{l}\text { Fish initial } \\
\text { weight }(\mathrm{g})\end{array}$ & Duration & $\begin{array}{l}\text { Replacement } \\
\%\end{array}$ & $\begin{array}{l}\text { FM \% } \\
\text { (base } \\
\text { diet) }\end{array}$ & $\begin{array}{l}\text { Growth } \\
\text { effect }\end{array}$ & Culture system & References \\
\hline Meat and bone meal & $1.88 \pm 0.02$ & 8 weeks & $\begin{array}{c}0,15,30,45,60 \\
75\end{array}$ & 55 & $\begin{array}{c}45 \% \text { no } \\
\text { differences }\end{array}$ & $\begin{array}{c}\text { Floating sea } \\
\text { cages } \\
(1.0 \times 1.0 \times 1.5 \mathrm{~m})\end{array}$ & $\begin{array}{l}\text { (Ai et al., } \\
\text { 2006) }\end{array}$ \\
\hline $\begin{array}{l}\text { Compound protein } \\
\text { sources (soybean } \\
\text { meal, meat and } \\
\text { bone meal, peanut } \\
\text { meal, and rapeseed } \\
\text { meal; } 4: 3: 2: 1 \text { ) }\end{array}$ & $1.88 \pm 0.01$ & 8 weeks & $\begin{array}{c}0,13,26,39,52 \\
65\end{array}$ & 48.8 & $\begin{array}{c}26 \% \text { no } \\
\text { differences }\end{array}$ & $\begin{array}{c}\text { Floating sea } \\
\text { cages } \\
(1.0 \times 1.0 \times 1.5 \mathrm{~m})\end{array}$ & $\begin{array}{c}\text { (Zhang, et } \\
\text { al., 2008) }\end{array}$ \\
\hline $\begin{array}{l}\text { Soybean meal, meat } \\
\text { and bone meal, } \\
\text { poultry by-product } \\
\text { meal, and peanut } \\
\text { meal }\end{array}$ & $23.3 \pm 0.96$ & 8 weeks & 30 & $42-60$ & $\begin{array}{l}\text { Peanut meal } \\
\text { with inferior } \\
\text { weight gain, } \\
\text { and specific } \\
\text { growth rate }\end{array}$ & $\begin{array}{c}\text { Floating sea } \\
\text { cages } \\
(1.5 \times 1.5 \times 2.0 \mathrm{~m})\end{array}$ & $\begin{array}{l}\text { (Li et al., } \\
\text { 2010) }\end{array}$ \\
\hline $\begin{array}{l}\text { Soybean protein } \\
\text { concentrate meal }\end{array}$ & $\begin{array}{c}10.50 \pm \\
0.04\end{array}$ & 56 days & $0,25,50,75,100$ & 40 & $\begin{array}{c}\text { No } \\
\text { differences }\end{array}$ & $\begin{array}{c}\text { Floating sea } \\
\text { cages } \\
(3.0 \times 3.0 \times 3.0 \mathrm{~m})\end{array}$ & $\begin{array}{l}\text { (Wang et } \\
\text { al., 2017) }\end{array}$ \\
\hline
\end{tabular}


significantly reducing growth.

Zhang et al. (2008) conducted feeding trials to evaluate the replacement of compound protein sources (soybean meal, meat and bone meal, peanut meal, and rapeseed meal; 4:3:2:1) for juvenile LYC (1.88g initial weight) for 8 weeks. Six isonitrogenous and isoenergetic diets were formulated to contain $0,9,18,27,36$, and $45 \%$ of the compound protein to replace $0,13,26,39$, 52 , and $65 \%$ of the fishmeal protein, respectively. The specific growth rates and feed efficiency ratios of fish fed the 13 and 26\% replacement diets were not significantly different from those of fish fed with the fishmeal diet, while those fed the $39-65 \%$ replacement diet were significantly lower than the fishmeal diet. The whole-body protein content, and methionine, cysteine and lysine contents significantly decreased with increased dietary compound protein levels (39-65\%). It was therefore concluded that the compound protein sources could replace about $26 \%$ of the fishmeal protein in the diets of LYC.
In another attempt to find an alternative to fishmeal, Li et al. (2010) evaluated the replacement of $30 \%$ of fishmeal with soybean meal, meat and bone meal, poultry by-product meal, or peanut meal in the practical diets of juvenile LYC (23.3g initial weight) for 8 weeks (Table 1). The results showed that fish fed with various protein sources had no significant differences in survival, weight gain, and specific growth rates, except for the peanut meal diet, which showed inferior weight gain and specific growth rate, and lower contents of crude protein, lipids, and carcass lysine.

In a study by Wang et al. (2017), the level of dietary soy protein replacement was even acclimated to a maximum of $100 \%$. Five isonitrogenous and isolipidic diets (45\% protein and $10 \%$ lipids) were formulated by replacing of fishmeal protein $(0,25,50,75$, and $100 \%$, respectively) with soybean protein concentrate meal. Among the dietary treatments, there were no significant differences in weight gain, specific growth rate, feed conversion ratio, and feed intakes;

Table 2. Replacement of fish oil by animal and vegetable resources

\begin{tabular}{|c|c|c|c|c|c|c|c|}
\hline $\begin{array}{l}\text { Replacement } \\
\text { sources }\end{array}$ & $\begin{array}{l}\text { Fish initial } \\
\text { weight }(\mathrm{g})\end{array}$ & Duration & $\begin{array}{c}\text { Replacement } \\
\%\end{array}$ & $\begin{array}{l}\mathrm{FO} \% \\
\text { (base } \\
\text { diet) }\end{array}$ & $\begin{array}{l}\text { Growth } \\
\text { effect }\end{array}$ & Culture system & References \\
\hline $\begin{array}{l}\text { Soybean oil and } \\
\text { beef tallow }\end{array}$ & $243.52 \pm 5.40$ & 9 weeks & 100 & 7.4 & $\begin{array}{c}\text { No } \\
\text { differences }\end{array}$ & $\begin{array}{c}\text { Floating sea } \\
\text { cages } \\
(2.0 \times 2.0 \times 2.0 \mathrm{~m})\end{array}$ & $\begin{array}{c}\text { (Wang et al., } \\
\text { 2012) }\end{array}$ \\
\hline $\begin{array}{l}\text { Soybean oil and } \\
\text { palm oil }\end{array}$ & $245.29 \pm 7.45$ & 12 weeks & $\begin{array}{c}0 \mathrm{SO}, 50 \mathrm{SO} \\
100 \mathrm{SO}, 100 \\
\text { PO }\end{array}$ & 6.4 & $\begin{array}{c}50 \text { SO, } 100 \\
\text { PO, no } \\
\text { differences }\end{array}$ & $\begin{array}{c}\text { Floating sea } \\
\text { cages } \\
(3.0 \times 3.0 \times 3.0 \mathrm{~m})\end{array}$ & $\begin{array}{c}\text { (Duan et al., } \\
\text { 2014) }\end{array}$ \\
\hline $\begin{array}{l}\text { Soybean, linseed, } \\
\text { rapeseed, and } \\
\text { peanut oil }\end{array}$ & $13.77 \pm 0.07$ & 8 weeks & 100 & 3.4 & $\begin{array}{c}\mathrm{SO}, \text { no } \\
\text { differences }\end{array}$ & $\begin{array}{c}\text { Floating net } \\
\text { cage } \\
(1.5 \times 1.5 \times 2.0 \mathrm{~m})\end{array}$ & $\begin{array}{l}\text { (Qiu et al., } \\
\text { 2017) }\end{array}$ \\
\hline $\begin{array}{l}\text { Vegetable oil } \\
\text { (soybean oil, } \\
\text { linseed oil) }\end{array}$ & $8.93 \pm 0.21$ & 10 weeks & $0,50,100$ & 9 & Decreased & Floating cages & $\begin{array}{l}\text { (Tan et al., } \\
\text { 2016) }\end{array}$ \\
\hline Soybean oil & $36.80 \pm 0.39$ & 12 weeks & 50,100 & 6.5 & Decreased & $\begin{array}{c}\text { Large sea } \\
\text { cages } \\
(4.0 \times 4.0 \times 4.0 \mathrm{~m})\end{array}$ & $\begin{array}{c}\text { (Mu et al., } \\
\text { 2018) }\end{array}$ \\
\hline $\begin{array}{l}\text { Soybean oil with } \\
\text { added dietary } \\
\text { chenodeoxycholic } \\
\text { acid }\end{array}$ & $10.03 \pm 0.02$ & 10 weeks & $\begin{array}{c}100 \mathrm{SO} \text { added } \\
\text { CDCA } 300,900 \\
\mathrm{mg} \mathrm{kg}^{-1}\end{array}$ & 6.0 & $\begin{array}{l}\text { CDCA } \\
\text { better }\end{array}$ & $\begin{array}{c}\text { Floating sea } \\
\text { cages } \\
(1.0 \times 1.0 \times 1.5 \mathrm{~m})\end{array}$ & $\begin{array}{c}\text { (Du et al., } \\
\text { 2017) }\end{array}$ \\
\hline Palm oil & $15.87 \pm 0.14$ & 70 days & $\begin{array}{c}0,33.3,66.7 \\
100\end{array}$ & 7.5 & $\begin{array}{l}66.7,100 \% \\
\text { suppressed }\end{array}$ & $\begin{array}{c}\text { Triplicate } \\
\text { floating cage } \\
(1 \times 1 \times 1.8 \mathrm{~m})\end{array}$ & $\begin{array}{l}\text { (Li et al., } \\
\text { 2019) }\end{array}$ \\
\hline
\end{tabular}

Note: FO: fish oil; SO: soybean oil; PO: palm oil; CDCA: chenodeoxycholic acid. 
the muscle protein and moisture contents also showed no significant differences. However, the lipid content was significantly lower in the dietary treatment with $100 \%$ soy protein replacement. The results also showed that the inclusion of soy protein with balanced dietary amino acids did not promote antioxidant capacities and affected the non-specific immune response of large yellow croaker.

Fish oil is a good source of lipids and has a high content of $n-3$ polyunsaturated fatty acids for marine fish nutritional requirements (Sargent \& Tacon, 1999). However, fish oil faces the challenges of high prices and unstable production due to the increasing demand for fishmeal and fish oil in aquaculture (Wang et al., 2017). To cut down the cost of feeding, some studies have tested different types of oil to replace the dietary fish oil used in aquaculture (Wang et al., 2012). Table 2 shows the studies that tested the replacement of fish oil with animal and vegetable resources in the literature. Some studies have demonstrated that the oil sources do not affect the growth performance of LYC grown-out fish (Wang et al., 2012; Duan et al., 2014) and juvenile LYC (Qiu et al., 2017).

In a 9 -week feeding trial conducted by Wang et al. (2012), three isonitrogenous and isoenergetic diets containing fish oil, soybean oil, and beef tallow, respectively, were studied to check their effects on the growth performance, tissue fatty acid composition, and peroxisome proliferator-activated receptor $\gamma$ gene expression in LYC grown-out fish (243.52g initial weight). No significant differences in weight gain, growth rate, and feed conversion rate were found among the different treatments after the trial. The fatty acid profiles of fish fillets and livers were influenced by the dietary fatty acid compositions, where the concentrations of eicosapentaenoic acid and docosahexaenoic acid decreased as the fish oil was replaced with soybean oil and beef tallow, respectively. The consumption of soybean oil displayed an increase of lipid accumulation in the liver and the expression of the peroxisome proliferator-activated receptor $\gamma$ gene that influences the function of lipid storage and metabolism.
Similarly, Duan et al. (2014) documented that replacing fish oil with 50\% soybean oil and 100\% palm oil resulted in no significant differences of the specific growth rate, condition factor, gutted yield, and colorimetric values of grown-out LYC (245.29g initial weight). Furthermore, five isonitrogenous and isolipidic experimental diets were formulated to check the effects of different lipid sources (fish, soybean, linseed, rapeseed, and peanut oil) on fish growth and the fatty acid compositions of juvenile LYC (13.77g initial weight) for 8 weeks (Qiu et al., 2017). The results suggested that different lipid sources could affect the fatty acid compositions in the muscles and livers of LYC in various metabolic pathways; and that soybean and palm oil can completely replace fish oil in the diets of LYC without suppressing the growth performance.

However, high levels of vegetable oil can suppress the growth and antioxidant capacity of juvenile LYC (Li et al., 2019; Tan et al., 2016; $\mathrm{Mu}$ et al., 2018). Three isonitrogenous and isolipid diets with 0,50 , and $100 \%$ vegetable oil were fed to juvenile LYC (8.93g initial weight) (Tan et al., 2016). The results showed that dietary vegetable oil could exert antiimmunological effects by altering TLR-NF- $\kappa B$ signaling, and elevating the inflammatory response by increasing the gene expression of pro-inflammatory cytokines (IL1b and TNFa) and decreasing the gene expression of antiinflammatory cytokines (arginase I and IL10). In addition, the replacement of 50 and $100 \%$ fish oil with soybean oil can suppress the growth performance, feed utilization, and antioxidation capacity of juvenile LYC (36.80g initial weight) (Mu et al., 2018). Similarly, a high percentage of dietary palm oil (66 and $100 \%$ ) supplemented to diets can suppress fish growth, antioxidant capacities, and induce the inflammatory response of juvenile LYC $(15.87 \mathrm{~g}$ initial weight) (Li et al., 2019). Fortunately, the imperfection of soybean oil replacement can be conquered with the supplementation of chenodeoxycholic acid ( 300 and $900 \mathrm{mg} \mathrm{kg}^{-1}$ ) to the diets of juvenile LYC (10.03g initial weight) (Du et al., 2017). The results of this study showed that chenodeoxycholic acid 
supplemented diets could improve the growth performance, body composition, and lipid deposition in the livers of LYC.

Some studies have reported the amino acid requirements of juvenile LYC (Table 3). The dietary methionine requirement was examined by Mai et al. (2006a) using six diets with graded levels of methionine $(0.66,0.89,1.13,1.41$, 1.67 , and $1.89 \%$ diets) for juvenile LYC (1.23 \pm $0.02 \mathrm{~g}$ initial weight). The specific growth rate, feed conversion efficiency, and protein efficiency ratio increased with increasing methionine levels up to the $1.41 \%$ diet and then declined. No significant differences in body composition were observed among the dietary treatments. It was therefore concluded that the optimum dietary level of methionine for juvenile LYC was the $1.44 \%$ diet. Zhang et al. (2008) examined the dietary lysine requirement for juveniles with six isonitrogenous and isoenergetic practical diets formulated with lysine $(1.27,1.83,2.41,3.02,3.60$, and $4.22 \%$ dry matter). The specific growth rate, feed efficiency ratio, protein efficiency ratio, and protein retention significantly increased with increasing lysine levels from 1.27 to $2.41 \%$ of the diet, and then leveled off. The whole-body protein and lysine contents increased significantly with the increasing dietary lysine levels, while the lipid contents showed an opposite trend to that of body protein. No significant differences were observed in moisture, ash, and other essential amino acids of the fish among the dietary treatments. It was concluded the optimum lysine requirements were $2.48,2.45$, and $2.43 \%$ of the diet, respectively, based on broken-line analysis of the specific growth rate, feed efficiency ratio, and protein efficiency ratio.

Large yellow croaker is a marine fish that has significant yellowness of skin color (Guo et al., 2018). Dietary natural pigments can enhance the natural skin pigmentation of LYC, such as xanthophylls, astaxanthin, and Haematococcus pluvialis (Chlorophyceae, order Volvocales) (Li et al., 2014; Yi et al., 2014) (Table 3). Xinwen Yi and his co-authors have studied the effects of xanthophylls and astaxanthin, compared

Table 3. Amino acid and other dietary nutrient requirements for juvenile large yellow croaker

\begin{tabular}{|c|c|c|c|c|c|}
\hline Dietary nutrients & $\begin{array}{l}\text { Experimented amount } \\
\text { (\% dry diet basic) }\end{array}$ & $\begin{array}{l}\text { Fish initial } \\
\text { weight }(\mathrm{g})\end{array}$ & Duration & Culture system & References \\
\hline Methionine & $\begin{array}{c}0.66,0.89,1.13,1.41 \\
1.67,1.89\end{array}$ & $1.23 \pm 0.02$ & $\begin{array}{c}10 \\
\text { weeks }\end{array}$ & $\begin{array}{l}\text { Floating net cages } \\
(1.0 \times 1.0 \times 1.5 \mathrm{~m})\end{array}$ & $\begin{array}{l}\text { (Mai et al., } \\
\text { 2006a) }\end{array}$ \\
\hline Lysine & $\begin{array}{c}1.27, \begin{array}{c}1.83,2.41,3.02 \\
3.60,4.22\end{array}\end{array}$ & $1.23 \pm 0.02$ & $\begin{array}{c}10 \\
\text { weeks }\end{array}$ & $\begin{array}{l}\text { Floating sea cages } \\
\quad(3.0 \times 3.0 \times 3.0 \mathrm{~m})\end{array}$ & $\begin{array}{c}\text { (Zhang, et al., } \\
\text { 2008) }\end{array}$ \\
\hline $\begin{array}{l}\text { Astaxanthin and } \\
\text { Haematococcus pluvialis }\end{array}$ & $\begin{array}{c}\text { Astaxanthin }(0.03,0.05 \\
0.10), H . \text { pluvialis }(0.28, \\
0.56,1.12)\end{array}$ & $5.57 \pm 0.01$ & 66 days & $\begin{array}{l}\text { Net cages } \\
(1.5 \times 1.5 \times 2.0 \mathrm{~m})\end{array}$ & (Li et al., 2014) \\
\hline $\begin{array}{l}\text { Astaxanthin and } \\
\text { xanthophylls }\end{array}$ & $\begin{array}{l}\text { Astaxanthin }\left(37.5,75^{\star}\right) \text {, } \\
\text { xanthophylls }\left(37.5,75^{\star}\right)\end{array}$ & $33.33 \pm 1.67$ & 9 weeks & $\begin{array}{l}\text { Floating sea cages } \\
\quad(3.0 \times 3.0 \times 3.0 \mathrm{~m})\end{array}$ & (Yi et al., 2014) \\
\hline $\begin{array}{l}\text { Xanthophylls/astaxanthin } \\
\text { ratio }\end{array}$ & $\begin{array}{c}75 / 0,50 / 25,37.5 / 37.5 \\
25 / 50,0 / 75^{\star}\end{array}$ & $13.80 \pm 0.03$ & 8 weeks & $\begin{array}{l}\text { Floating sea cages } \\
\quad(1.0 \times 1.0 \times 1.5 \mathrm{~m})\end{array}$ & (Yi et al., 2015) \\
\hline $\begin{array}{l}\text { Astaxanthin and vitamin } \\
\mathrm{E}\end{array}$ & $\begin{array}{l}\text { Astaxanthin }\left(25,50^{*}\right) \text {, } \\
\text { vitamin } E\left(0,120,800^{*}\right)\end{array}$ & $3.00 \pm 0.01$ & $\begin{array}{c}10 \\
\text { weeks }\end{array}$ & $\begin{array}{l}\text { Floating sea cages } \\
(1.5 \times 1.5 \times 2.0 \mathrm{~m})\end{array}$ & (Yi et al., 2018) \\
\hline Phosphorus & $0.30,0.55,0.69,0.91$ & $1.88 \pm 0.02$ & 8 weeks & $\begin{array}{l}\text { Floating sea cages } \\
\quad(1.0 \times 1.0 \times 1.5 \mathrm{~m})\end{array}$ & $\begin{array}{l}\text { (Mai et al., } \\
\text { 2006b) }\end{array}$ \\
\hline Copper & $\begin{array}{c}2.61,3.25,4.65,7.16 \\
11.38,18.45^{\star}\end{array}$ & $9.18 \pm 0.06$ & $\begin{array}{c}10 \\
\text { weeks }\end{array}$ & $\begin{array}{l}\text { Floating sea cages } \\
\quad(3.0 \times 3.0 \times 3.0 \mathrm{~m})\end{array}$ & $\begin{array}{l}\text { (Cao et al., } \\
\text { 2014) }\end{array}$ \\
\hline Citric acid & $0.4,0.8,1.6,3.0$ & $7.71 \pm 0.02$ & 9 weeks & $\begin{array}{l}\text { Floating sea cages } \\
(1.5 \times 1.5 \times 2.0 \mathrm{~m})\end{array}$ & $\begin{array}{l}\text { (Zhang et al., } \\
\text { 2016) }\end{array}$ \\
\hline Tea polyphenols & $0,0.01,0.02,0.05$ & $15.88 \pm 0.12$ & 70 days & $\begin{array}{c}\text { Net cages } \\
(1.0 \times 1.0 \times 2.0 \mathrm{~m})\end{array}$ & (Ji et al., 2018) \\
\hline
\end{tabular}

Note: ${ }^{*}, \mathrm{mg} \mathrm{kg}^{-1}$. 
to a basal diet, on fish growth, skin pigmentation, and carotenoid concentration of LYC (Yi et al., 2014; Yi et al., 2015; Yi et al., 2018). In general, the survival rate, specific growth rate, and protein efficiency ratio were not significantly different among treatments. A higher yellowness $\left(b^{*}\right)$ value and carotenoid concentration were observed in both the dorsal and ventral skins of fish with increased xanthophyll levels than those with increased astaxanthin levels, which were both higher than those of the basal diet.

Li et al. (2014) studied the effects of dietary

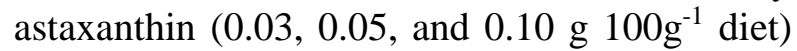
and Haematococcus pluvialis ( $H$. pluvialis)

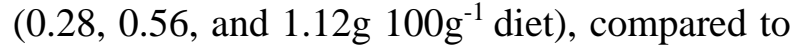
a basal diet, on fish growth, antioxidant status, and, especially, the immune response of LYC (initial weight $5.57 \mathrm{~g}$ ) for 66 days. No significant differences were observed in the fish survival rate, food conversion ratio, protein efficiency ratio, and hepatosomatic index among the different treatments. Weight gain and wholebody lipid content were highest in the $H$. pluvialis treatment, compared to the astaxanthin and basal diets. The condition factor of the $H$. pluvialis treatment was significantly higher than that of astaxanthin, which was similar to that of the basal diet. It was found that LYC with astaxanthin and $H$. pluvialis had lower glucose, triglyceride, and cholesterol levels than those of fish fed a basal diet. Serum lysozyme activity, an index of innate immunity, was reported to increase with increased dietary astaxanthin or $H$. pluvialis levels. The complement response, acting as a bactericidal agent in serum and mucus, was also found to improve in large yellow croaker fed with astaxanthin or $H$. pluviali.

Other dietary nutrient requirement studies have also reported the optimal concentrations for juvenile LYC, e.g. dietary phosphorus 0.89$0.91 \%$ of diet (Mai et al., 2006b), dietary copper $3.41 \mathrm{mg} \mathrm{kg}^{-1}$ (Cao et al., 2014), dietary citric acid $0.8-1.6 \%$ diet (Zhang et al., 2016), and dietary tea polyphenols $0.01-0.02 \%$ diet (Ji et al., 2018) (Table 3). Recently, dietary requirements have been inter-studied with the biological functions of fish, i.e. antioxidant capacity (Yi et al., 2018), immune response (Zuo et al., 2012a; Li et al., 2014), intestinal digestive enzyme activities
(Zhang et al., 2016), lipid metabolism genes expression (Ji et al., 2018), and disease resistance (Zuo et al., 2012a). These studies contribute to the holistic understanding of the physiological mechanisms behind the fish traits and their reactions to certain dietary nutrients.

\section{Conclusions and Future Perspectives}

As one of the most financially important marine fish farmed in China, large yellow croaker aquaculture is gaining attention from the Chinese government, culturists, technicians, and scientists. This article presents an overview of large yellow croaker aquaculture in China, providing related information about the general biology, aquaculture development, culture systems, and nutrition management of large yellow croaker. The floating sea cage is the main model of LYC aquaculture; however, novel aquaculture systems such as the storm-resistance deep-sea cage and indoor recirculation system have great potential for large-scale aquaculture production. The ideal marine juvenile diet for LYC is one containing the protein: lipid ratio of 47:10.5; likewise, other nutrient requirements have also been studied recently.

Important research efforts should continue in the field of culture systems for LYC, and should support the sustainable development and environmental safety of marine aquaculture. Currently, the installation and operation of submersible offshore sea-cages are attracting investments from operators and managers, and this system can be utilized for LYC depending on the local circumstances, the resources of each farm business, and the continuous innovation of the culturists, managers, and scientists.

To reduce the price of the diets fed to LYC and triumph over the unstable availability of fishmeal and fish oil, studies about the replacement of protein and lipid sources should continue to be carried out on other protein and lipid sources and vegetable oils. In addition, investigations on dietary supplementations, such as dietary amino acids, phospholipids, and n-3 highly unsaturated fatty acids, are needed to determine the favored sources of metabolic energy for LYC. Moreover, further research 
about the physiological responses to particular dietary nutrients of LYC will contribute to our understanding of fish metabolism, help protect the fish from disease, and allow increases in large-scale fish production.

\section{Acknowledgements}

We are grateful to Mr. Truong Huu Dieu and Mrs. Huynh Thi Lieng for their help and contributions.

\section{Conflicts of Interest}

The authors declare no conflicts of interest.

\section{References}

Ai Q., Mai K., Tan B., Xu W., Duan Q., Ma H. \& Zhang L. (2006). Replacement of fish meal by meat and bone meal in diets for large yellow croaker, Pseudosciaena crocea. Aquaculture. 260: 255-263.

Ai Q. H., Zhao J. Z., Mai K. S., Xu W., Tan B. P., Ma H. M. \& Liufu Z. G. (2008). Optimal dietary lipid level for large yellow croaker (Pseudosciaena crocea) larvae. Aquaculture Nutrition. 14(6): 515-522.

Cao J., Miao X., Xu W., Li J., Zhang W. \& Mai K. (2014). Dietary copper requirements of juvenile large yellow croaker Larimichthys croceus. Aquaculture. 432: 346350 .

Chen S., Su Y. \& Hong W. (2018). Aquaculture of the Large Yellow Croaker. Aquaculture in China: Success Stories and Modern Trends. 297-308.

Chen Y., Huang W., Shan X., Chen J., Weng H., Yang T. \& Wang H. (2020). Growth characteristics of cagecultured large yellow croaker Larimichthys crocea. Aquaculture Reports. 16: 100242.

Conceição L. E. C., Grasdalen H. \& Rønnestad I. (2003). Amino acid requirements of fish larvae and postlarvae: new tools and recent findings. Aquaculture. 227: 221-232.

Du J., Xu H., Li S., Cai Z., Mai K. \& Ai Q. (2017). Effects of dietary chenodeoxycholic acid on growth performance, body composition and related gene expression in large yellow croaker (Larimichthys crocea) fed diets with high replacement of fish oil with soybean oil. Aquaculture. 479: 584-590.

Duan Q., Mai K., Zhong H., Si L. \& Wang X. (2001). Studies on the nutrition of the large yellow croaker, Pseudosciaena crocea R. I: growth response to graded levels of dietary protein and lipid. Aquaculture Research. 32(1): 46-52.

Duan Q., Mai K., Shentu J., Ai Q., Zhong H., Jiang Y., Zhang L., Zhang C. \& Guo S. (2014). Replacement of dietary fish oil with vegetable oils improves the growth and flesh quality of large yellow croaker (Larmichthys crocea). Journal of Ocean University of China. 13(3): 445-452.

FAO (2018). The State of World Fisheries and Aquaculture: Opportunities and Challenges. Rome: Food and Agriculture Organization of the United Nations.

Fishery Bureau (2011). Annual report of fishery statistic China. China: Agriculture Press of China (in Chinese).

Fishery Bureau (2017). Annual report of fishery statistic China. China: Agriculture Press of China (in Chinese).

Fishery Bureau (2018). Annual report of fishery statistic China. China: Agriculture Press of China (in Chinese).

Guo Q., Song W., Jiang C., Jiang K., Li X.-Y. \& Wang L. (2016). Comparison of nutritional quality and heavy metals of Pseudosciaena crocea in different farmed modes. Science \& Technology of Food Industry. 37(6): 341-345 (in Chinese with English abstract).

Guo Q., Truonghuynh T., Jiang C., Wang L., Li B. \& Xing X. (2018). Quality Differences of Large Yellow Croaker (Pseudosciaena crocea) Cultured in DeepWater Sea Cages of Two China Regions. Journal of Aquaculture Research and Development. 09(09): 1-8.

Han K. H., Huang W. Q. \& Dai Y. B. (2011). Comparison and analysis of the nutrient components of Larimichthys crocea in seine net and traditional net cage. Hebei Fisheries. 135(2): 217-224 (in Chinese with English abstract).

Hong W., Liu J., Zheng W., Han K. \& Liu Z. (2018). Transformation and upgrading countermeasure for the large yellow croaker industry in China. Journal of Fisheries Research. 40(4): 315-323 (in Chinese with English abstract).

Huang B. \& Walters C. J. (1983). Cohort analysis and population dynamics of large yellow croaker in the China Sea. North American Journal of Fisheries Management. 3(3): 295-305.

Huang W. (2015). Techniques on Large Yellow Croaker Culture in Freshwater. Fisheries Science. 34(5): $327-$ 330 (in Chinese with English abstract).

Ji R., Li Y., Li X., Xiang X., Li Y., Zhu S., Yang B., Zhang Y., Mai K. \& Ai Q. (2018). Effects of dietary tea polyphenols on growth, biochemical and antioxidant responses, fatty acid composition and expression of lipid metabolism related genes of large yellow croaker (Larimichthys crocea). Aquaculture Research. 49(3): 1210-1218.

Jiang C. (2014). The simulated ecological earthen-pond culture of large yellow croaker. Scientific Fish Farming. 30(3): 43 (in Chinese).

Li J., Zhang L., Mai K., Ai Q., Zhang C., Li H., Duan Q., Ma H., Zhang L. \& Zheng S. (2010). Potential of several protein sources as fish meal substitutes in diets for large yellow croaker, Pseudosciaena crocea R. Journal of the World Aquaculture Society. 41: 278-283.

Li M. Y., Miao L., Chen J., Chen Q. J. \& Yu C. (2017). Establishment and discussion on the new model of 
simulated ecological and grading aquaculture for large yellow croaker. Journal of Ningbo University. 30(2): $1-5$.

Li M., Wu W., Zhou P., Xie F., Zhou Q. \& Mai K. (2014). Comparison effect of dietary astaxanthin and Haematococcus pluvialis on growth performance, antioxidant status and immune response of large yellow croaker Pseudosciaena crocea. Aquaculture. 434: 227-232.

Li W., Ai Q., Mai K., Xu W., Luo Y. \& Zhang Y. (2013). Effects of dietary amino acid patterns on growth and protein metabolism of large yellow croaker (Larimichthys crocea) larvae. Aquaculture. 406: 1-8.

Li X., Ji R., Cui K., Chen Q., Chen Q., Fang W., Mai K., Zhang Y., Xu W. \& Ai Q. (2019). High percentage of dietary palm oil suppressed growth and antioxidant capacity and induced the inflammation by activation of TLRNFKB signaling pathway in large yellow croaker (Larimichthys crocea). Fish \& Shellfish Immunology.

Liao H. M., Lin P. H. \& Gao J. (2011). Current Situation and Countermeasures of Pseudosciaena crocea Cultivation in Ningde City of Fujian Province. Guizhou Agricultural Sciences. 39(1): 165-168 (in Chinese with English abstract).

Lin X. (1987). Biological characteristics and resources status of three main commercial fishes in offshore waters of China. Journal of Fisheries of China. 11(3): 187-194 (in Chinese with English abstract).

Liu J. F. (2013). Large yellow croaker breeding and biology. Xiamen, China: Xiamen University Press (Chinese Edition).

Liu M., Mitcheson D. \& Sadovy Y. (2008). Profile of a fishery collapse: why mariculture failed to save the large yellow croaker. Fish and Fisheries. 9(3): 219242.

Liu Z. K. (2014). Present research condition of Larimichthys crocea feed in Ningde of Fujian province. Journal of Ningde Normal University. 26(3): 229-234 (in Chinese with English abstract).

Liu Z. Y. \& Li Y. P. (2001). Present situation of feed for Pseudosciaena crocea in Mindong and its countermeasures. Journal of Oceanography in Taiwan Strait. 20: 180-183 (in Chinese with English abstract).

Lü H., Xu J. \& Vander H. G. (2008). Supplementing marine capture fisheries in the East China Sea: Sea ranching of prawn Penaeus orientalis, restocking of large yellow croaker Pseudosciaena crocea, and cage culture. Reviews in Fisheries Science. 16(1-3): 366376.

Mai K., Wan J., Ai Q., Xu W., Liufu Z., Zhang L., Zhang C. \& Li H. (2006a). Dietary methionine requirement of large yellow croaker, Pseudosciaena crocea R. Aquaculture. 253(1-4): 564-572.

Mai K., Zhang C., Ai Q., Duan Q., Xu W., Zhang L., Liufu Z. \& Tan B. (2006b). Dietary phosphorus requirement of large yellow croaker, Pseudosciaena crocea R. Aquaculture. 251(2-4): 346-353.
Miao F. R. \& Li Z. R. (2006). The simulated ecological enclosure net culture of large yellow croaker. Journal of aquaculture. 27(3): 22-23 (in Chinese).

Miao F. R., Liu J., Wang D.-H., Feng Y. L. \& Li Z. R. (2007). Meat quality of Pseudosciaena crocea cultivated by different methods. Fujian Journal of Agricultural Sciences. 22(4): 372-377 (in Chinese with English abstract).

Miao L., Li M.-Y., Chen J. \& Zhang H. (2014). Breeding of Fast Growth and Low Temperature Tolerance of New Variety Donghai No.1 Large Yellow Croaker (Pseudosciaena crocea). Journal of Agricultural Biotechnology. 22(10): 1314-1320.

Mu H., Shen H., Liu J., Xie F., Zhang W. \& Mai K. (2018). High level of dietary soybean oil depresses the growth and anti-oxidative capacity and induces inflammatory response in large yellow croaker Larimichthys crocea. Fish \& Shellfish Immunology. 77: 465-473.

Ni H. E. \& Lu J.-h. (2003). Present utilization situation of main fishery resources in Zhoushan fishing ground. Chinese Journal of Applied Ecology. 14(4): 569-572 (in Chinese with English abstract).

Ni H.-E. \& Wang G.-L. (2009). Relationship between diseases in large yellow croaker (Pseudosciaena crocea) in marine cage culture and environmental factors. Oceanologia Et Limnologia Sinica. 40(1): 7277 (in Chinese with English abstract).

Qiu H., Jin M., Li Y., Lu Y., Hou Y. \& Zhou Q. (2017). Dietary lipid sources influence fatty acid composition in tissue of large yellow croaker (Larmichthys crocea) by regulating triacylglycerol synthesis and catabolism at the transcriptional level. Plos One. 12(1): e0169985.

Rønnestad I., Tonheim S. K., Fyhn H. J., Rojas-Garcıa C. R., Kamisaka Y., Koven W., Finn R. N., Terjesen B. F., Barr Y. \& Conceição L. E. C. (2003). The supply of amino acids during early feeding stages of marine fish larvae: a review of recent findings. Aquaculture. 227(1-4): 147-164.

Sargent J. R. \& Tacon A. G. J. (1999). Development of farmed fish: a nutritionally necessary alternative to meat. proceedings of the Nutrition Society. 58(2): 377 383.

Su Y. Q., Zhang C. L. \& Wang J. (2004). Breeding and farming of Pseudosciaena crocea. Beijing, China: Ocean Press (in Chinese).

Tan P., Dong X., Mai K., Xu W. \& Ai Q. (2016). Vegetable oil induced inflammatory response by altering TLR$\mathrm{NF}-\kappa \mathrm{B}$ signalling, macrophages infiltration and polarization in adipose tissue of large yellow croaker (Larimichthys crocea). Fish \& Shellfish Immunology. 59: 398-405.

Wang L., Shi X., Su Y., Meng Z. \& Lin H. (2013). Genetic divergence and historical demography in the endangered large yellow croaker revealed by mtDNA. Biochemical Systematics and Ecology. 46: 137-144.

Wang P., Zhu J., Feng J., He J., Lou Y. \& Zhou Q. (2017). Effects of dietary soy protein concentrate meal on 
growth, immunity, enzyme activity and protein metabolism in relation to gene expression in large yellow croaker Larimichthys crocea. Aquaculture. 477: $15-22$.

Wang X. C. (2014). Influence of soft pelleted diet and fresh trash fish surimi on water quality in large yellow croaker (Pseudosciaena crocea). Fisheries Science. 33(10): 635-638 (in Chinese with English abstract).

Wang X. X., Li Y. J., Hou C. L., Gao Y. \& Wang Y. Z. (2012). Influence of different dietary lipid sources on the growth, tissue fatty acid composition, histological changes and peroxisome proliferator-activated receptor $\gamma$ gene expression in large yellow croaker (Pseudosciaena crocea R.). Aquaculture Research. 43(2): 281-291.

Wang X., Celander M. C., Yin X., Zhang Z., Chen Y., Xu H., Yu X., Xu K., Zhang X. \& Kanchanopas-Barnette P. (2019). PAHs and PCBs residues and consumption risk assessment in farmed yellow croaker (Larimichthys crocea) from the East China Sea, China. Marine Pollution Bulletin. 140: 294-300.

Wang Y., Li W., Li L., Wei Z. \& Lu W. (2016). Effects of salinity on the physiological responses of the large yellow croaker Pseudosciaena crocea under indoor culture conditions. Aquaculture Research. 47(11): 3410-3420.

Wang Y., Xu X., Yan Q., Xiong H., Deng F. \& Ma Y. (2014). Bacterial composition in feed mash of fresh frozen trash fish for large yellow croaker (Larimichthys crocea). South China Fisheries Science. 10(3): 53-57 (in Chinese with English abstract).

Wang Z., Chen C., Guo Y. \& Liu C. (2014). High sequence variation and low population differentiation of mitochondrial control regions of wild large yellow croaker in South China Sea. Biochemical Systematics and Ecology. 56: 151-157.

Xiao X., Lin S., Wu X. \& Zheng Z. (2017). Volatile flavor compounds on the skin and scales of Pseudosciaena crocea cultured using three different methods. Journal of Fishery Sciences of China. 24(2): 341-354 (in Chinese with English abstract).

Xie F., Ai Q., Mai K., Xu W. \& Wang X. (2012). Dietary lysine requirement of large yellow croaker (Pseudosciaena crocea, Richardson 1846) larvae. Aquaculture Research. 43(6): 917-928.

Yan S. A., Yao Q. H., Lin X. X., Lin Q. \& Su D. S. (2015). Nutrient profile of large yellow croakers (Pseudosciaena crocea Richardson) grown under different aquacultural settings. Fujian Journal of Agricultural Sciences. 30(8): 736-744 (in Chinese with English abstract).

Yi X., Shen H., Li J., Wei Z., Shentu J., Zhang W. \& Mai K. (2018). Effects of dietary vitamin E and astaxanthin on growth, skin colour and antioxidative capacity of large yellow croaker Larimichthys crocea. Aquaculture Nutrition. 24(1): 472-480.
Yi X., Xu W., Zhou H., Zhang Y., Luo Y., Zhang W. \& Mai K. (2014). Effects of dietary astaxanthin and xanthophylls on the growth and skin pigmentation of large yellow croaker Larimichthys croceus. Aquaculture. 433: 377-383.

Yi X. W., Li J., Xu W., Zhang Y. J., Zhou H. H., Smith A.A., Zhang W. B. \& Mai K. S. (2015). Effects of dietary xanthophylls/astaxanthin ratios on the growth and skin pigmentation of large yellow croaker Larimichthys crocea (Richardson, 1846). Journal of Applied Ichthyology. 31(4): 780-786.

Yin Y., Gao J. \& Liu Y. (2017). Influence of industrial organizational structure on farming performance of large yellow croaker farmers. Aquaculture and fisheries. 2(3): 134-139.

Yu H., Ai Q., Mai K., Ma H., Cahu C. L. \& Zambonino Infante J. L. (2012). Effects of dietary protein levels on the growth, survival, amylase and trypsin activities in large yellow croaker, Pseudosciaena Crocea R., larvae. Aquaculture Research. 43(2): 178-186.

Zhang C.-L., Liu J.-F., Li Y.-C. \& Chen Z. (2002). Analysing the present condition and countermeasure of cultured large yellow croaker Pseudosciaena crocea in Fujian Province. Journal of Shanghai Fisheries University. 11(1): 77-83 (in Chinese with English abstract).

Zhang C., Ai Q., Mai K., Tan B., Li H. \& Zhang L. (2008). Dietary lysine requirement of large yellow croaker, Pseudosciaena crocea R. Aquaculture. 283(1-4): 123-127.

Zhang H., Yi L., Sun R., Zhou H., Xu W., Zhang W. \& Mai K. (2016). Effects of dietary citric acid on growth performance, mineral status and intestinal digestive enzyme activities of large yellow croaker Larimichthys crocea (Richardson, 1846) fed high plant protein diets. Aquaculture. 453: 147-153.

Zhang L., Mai K., Ai Q., Duan Q., Zhang C., Li H. \& Tan B. (2008). Use of a Compound Protein Source as a Replacement for Fish Meal in Diets of Large Yellow Croaker, Pseudosciaena crocea R. Journal of the World Aquaculture Society. 39(1): 83-90.

Zhang Q.1. (2003). Deep-water sea cage culture of large yellow croaker. Fishery Modernization. 3: 8-10 (in Chinese).

Zhao J., Ai Q., Mai K., Zuo R. \& Luo Y. (2013). Effects of dietary phospholipids on survival, growth, digestive enzymes and stress resistance of large yellow croaker, Larmichthys crocea larvae. Aquaculture. 410: 122-128.

Zhong A., Chu Z., Dai L. \& Wang X. (2014). Evaluation of Nutrient Components and Nutritive Quality of Larimichthys crocea (Big Yellow Croaker) in Different Aquaculture Models. Animal Husbandry \& Feed Science. 6(6): 296-299.

Zhou P., Jin M., Wenjun W., Jikang S., Ming L. \& Zhou Q. (2014). Comparison of Nutrient Components of Large Yellow Croaker (Pseudosciaena crocea Richardson) Cultured in Different Modes, Fed Different Feeds and from 
Different Strains. Chinese Journal of Animal Nutrition. 26(4): 969-980 (in Chinese with English abstract).

Zuo R., Ai Q., Mai K., Xu W., Wang J., Xu H., Liufu Z. \& Zhang Y. (2012a). Effects of dietary docosahexaenoic to eicosapentaenoic acid ratio (DHA/EPA) on growth, nonspecific immunity, expression of some immune related genes and disease resistance of large yellow croaker (Larmichthys crocea) following natural infestation of parasites (Cryptocaryon irritans).
Aquaculture. 334: 101-109.

Zuo R., Ai Q., Mai K., Xu W., Wang J., Xu H., Liufu Z. \& Zhang Y. (2012b). Effects of dietary n-3 highly unsaturated fatty acids on growth, nonspecific immunity, expression of some immune related genes and disease resistance of large yellow croaker (Larmichthys crocea) following natural infestation of parasites (Cryptocaryon irritans). Fish \& Shellfish Immunology. 32(2): 249-258. 